prof. dr hab. Dorota Żołądź-Strzelczyk, główna pomysłodawczyni i inicjatorka tego spotkania naukowego oraz dr Jolanta Podsiadło.

Konferencja „Od grzechotki do klocków Lego - dawne i współczesne zabawki dziecięce” nie tylko „udowodniła”, że tematyka świata zabawek, na pozór zepchnięta w niszę badań naukowych, jest znacząco obecna w wielu dziedzinach nauki. Interdyscyplinarne spotkanie wykazało, że mimo mówienia „specyficznym” językiem poszczególnych dyscyplin naukowych, wszyscy doceniają rolę zabawki w rozwoju i życiu dziecka oraz w historii samego dzieciństwa.

Owocem konferencji jest także podjęcie dalszych inicjatyw naukowych - spotkań poświęconych wieloaspektowym badaniom nad zabawką, która była, jest i będzie nadal bardzo ważnym towarzyszem dzieciństwa - czy tylko dzieciństwa?

Kinga Jackowska

Katarzyna Kabacińska

\title{
Krakowskie środowisko historyków wychowania w drugiej połowie XX wieku (Kraków, 11-12 stycznia 2009)
}

W stycznia 2009 roku odbyła się w Krakowie konferencja naukowa na temat: Krakowskie środowisko historyków wychowania w drugiej połowie XX wieku. Zorganizowała ją Katedra Historii Oświaty i Wychowania Uniwersytetu Pedagogicznego w Krakowie, którą wspierały Towarzystwo Historii Edukacji i Zakład Historii Oświaty i Kultury Uniwersytetu Jagiellońskiego. Konferencja spotkała się z dużym zainteresowaniem w środowisku historyków wychowania w całej Polsce.

W programie konferencji przewidziano spotkanie poświęcone jubileuszowi Profesora dr hab. Zygmunta Ruty oraz naukowe, które miało przedstawić dokonania krakowskiego środowiska historyków wychowania w drugiej połowie XX wieku i jego związkom z innymi ośrodkami naukowymi w Polsce. Uroczyste spotkanie pierwszego dnia, które odbyło się w Wieliczce, poświecone było jubileuszowi siedemdziesięciolecia urodzin i pięćdziesięciolecia pracy dydaktycznej oraz naukowej Profesora dr hab. Zygmunta Ruty. Uczestniczyli w nim: Dziekan Wydziału Humanistycznego Uniwersytetu Jagiellońskiego prof. dr hab. Andrzej Banach, Dziekan Wydziału Humanistycznego Uniwersytetu Pedagogicznego w Krakowie prof. dr hab. Kazimierz Karolczak, były Rektor Uniwersytetu Pelagicznego w Krakowie prof. dr hab. Feliks Kiryk oraz liczne grono przyjaciół i najbliższa rodzina Profesora. Ważnym punktem programu pierwszego dnia była laudacja na część Profesora Zygmunta Ruty wygłoszona przez prof. dr hab. Stanisława Gawlika i prof. dr hab. Krzysztofa Jakubiaka. Wygłaszający laudacje przedstawili drogę 
życiową i naukową Profesora Zygmunta Ruty, pracę w Katedrze Historii Oświaty i Wychowania Wyższej Szkoły Pedagogicznej w Krakowie (obecnie Uniwersytet Pedagogiczny w Krakowie) oraz ukazali liczne związki Profesora z krakowskim i polskim środowiskiem historyków wychowania.

Program drugiego dnia konferencji obejmował pięć wystąpień. Prof. dr hab. Zygmunt Ruta zaprezentował sylwetkę profesora Czesława Majorka jako wybitnego nauczyciela, humanistę, badacza dziejów szkolnictwa i myśli pedagogicznej, utrzymującego liczne kontakty naukowe z wieloma ośrodkami naukowymi w Polsce i na świecie. Prof. dr hab. Kalina Bartnicka i prof. dr hab. Irena Szybik przedstawiły wzajemne relacje pomiędzy krakowską i warszawską szkołą historyków wychowania. Prof. dr hab. Władysława Szulakiewicz opisała naukowe związki Lwowa i Krakowa oraz losy lwowskich historyków wychowania, którzy w pierwszej połowie dwudziestego wieku przenieśli się do Krakowa. Prof. dr hab. Julian Dybiec omówił problematykę historii wychowania w pracach magisterskich i doktorskich studentów Uniwersytetu Jagiellońskiego, a prof. dr hab. Jana Krukowski przedstawił historię oświaty i wychowania w strukturze organizacyjnej, badawczej oraz dydaktycznej Uniwersytetu Pedagogicznego w Krakowie.

Konferencji towarzyszyła wystawa prac i dokonań naukowych pracowników Katedry Historii Oświaty i Wychowania Uniwersytetu Pedagogicznego w Krakowie, którą przygotował dział Informacji Naukowej Biblioteki Głównej UP w Krakowie. Wystawa ukazała naukowy i organizacyjny dorobek Katedry, istniejącej ponad trzydzieści lat. Przedstawiony został główny nurt badawczy obrazujący dzieje oświaty, nauki i myśli pedagogicznej w Polsce od XV do XX wieku oraz pokazano rezultaty wzajemnych przedsięwzięć naukowych prowadzonych wspólnie z Pracownią Biografistyki Instytutu Historii Uniwersytetu Pedagogicznego w Krakowie, kilkuletnią współpracę Katedry z Komisją Nauk Pedagogicznych PAN Oddział w Krakowie i podobnymi ośrodkami naukowymi w Europie, USA, Kanadzie, Japonii.

Ryszard Ślęczka 